\title{
Scientific Authority in the Creation-Evolution Debates
}

\author{
Finn R. Pond • Jean L. Pond
}

Published online: 15 July 2010

(C) Springer Science+Business Media, LLC 2010

\begin{abstract}
At the heart of debates among creationists and evolutionists are questions about scientific integrity and rigor. Creationists often justify their rejection of biological evolution by claiming that the methodologies and interpretations of evolutionary scientists are flawed. A consideration of creationists' critiques of the scientific data, however, reveals a deficient understanding and appreciation of the nature of the scientific process. It is essential that our schools educate students about the character of scientific inquiry. Clarifying the nature and limitation of scientific knowledge for our students will equip our students to evaluate evolutionary or creationist arguments critically. Recognizing and teaching both the strengths and limitations of the scientific process will do much to further the ongoing dialogue between science and religion.
\end{abstract}

Keywords Evolution · Creation · Scientific method Intelligent design $\cdot$ Methodological naturalism

\section{Introduction}

Science is a powerful way of knowing about the natural world. Technological and engineering successes and advancements in modern times depend upon the ability of scientific inquiries to reveal the workings of the natural world, of matter and energy, and are therefore evidences of this power. Yet people often display an ambivalent attitude

F. R. Pond $(\bowtie) \cdot J$. L. Pond

Whitworth University,

300 W. Hawthorne Rd.,

Spokane, WA 99251, USA

e-mail: fpond@whitworth.edu toward science - promoting, using, and respecting science, but wanting to control it and calling upon it to reinforce their view of reality. This ambivalence is evident especially when scientific findings run counter to religious or philosophical convictions. A case in point is human evolution, which challenges some religious views of human origins.

Reality, however, is not subject to human decree. It is what it is and will remain so despite any desire that it conform to a particular political, ideological, or theological dogma. Consequently, we cannot dismiss scientific explanations of natural phenomena because we dislike or disapprove of the universe described. Yet, this is exactly what some people attempt. Objections to the theory of evolution motivate various groups to compete for authority over the biological sciences in our nation's classrooms. Whether hidden in the language of free speech, fairness, the nature of science, or the search for truth, anti-evolutionists have fought for many years to shape textbook presentations and public school science curricula to counter established scientific understandings. ${ }^{1}$

The biological community considers the evidence for evolution overwhelming and beyond dispute. Numerous statements by scientific organizations unequivocally endorse the teaching of evolution as a well-documented and

\footnotetext{
${ }^{1}$ See for example the following articles and books which discuss the teaching of evolution in public schools: Bergman (1999), Terry (2004), Jones (2005), Scott (2007), Antolin and Herbers (2001), Forrest and Gross (2005). Discovery Institute (2005b), Scott and Branch (2006), Scott and Matzke (2007), Forrest and Gross (2007), Forrest (2007), Discovery Institute (2007), Scott (2009). See also: AntiEvolution.org http://www.antievolution.org/ $\mathrm{cs} /$ (AntiEvolution.org tracks activity and issues in the creationevolution debates).
} 
scientifically important theory. ${ }^{2}$ A recent poll by the Pew Research Center and American Association for the Advancement of Science indicated that $97 \%$ of scientists agree that humans and other organisms evolved over time, and $87 \%$ of scientists, compared to $32 \%$ of the public, specified that evolution occurred by natural processes (The Pew Research Center for the People and the Press 2009). Biologists continue to discuss and debate the mechanisms, patterns, and details of evolution, but the certainty of evolution is not in question. ${ }^{3}$ With only negligible dissent, the community declares that "descent with modification" as laid out by Darwin (1859) accurately describes the general historical pattern of life on earth. This conclusion is built upon countless observations and thousands of rigorous studies and experiments from all disciplines in the biological sciences over a period of 150 years. Now, even more than in 1973, the statement of Theodosius Dobzhansky, the great evolutionary geneticist, is true: "Nothing in biology makes sense except in the light of evolution" (Dobzhansky 1973b).

Nevertheless, polls continue to show widespread distrust of evolutionary science among the American public (Miller et al. 2006; Berkman et al. 2008; Newport 2009; Keeter and Horowitz 2009). Acceptance of evolution correlates with levels of education $(21 \%$ for individuals with a high school education or less, $55 \%$ for college graduates, and $74 \%$ for individuals with postgraduate degrees; Newport 2009). Such data suggest that critical reasoning skills, exposure to evolutionary theory, or deeper understanding of the nature of scientific inquiry and scientific evidence might be factors in transforming people's thinking about evolution. This cannot be the sole explanation for the low rate of acceptance of evolution in the U.S., however, since a 2006 survey revealed that the U.S. ranked second among 33 countries in scientific literacy (Miller 2006) yet in another study ranked second lowest among 32 countries in the percentage of persons accepting evolution (Miller et al. 2006). Only Turkey (which had a scientific literacy rate of

\footnotetext{
${ }^{2}$ Sager. Voices for evolution, 3rd ed., National Center for Science Education; Included are statements from the following national scientific organizations: American Anthropological Association, American Association for the Advancement of Science, American Association of Physical Anthropologists, American Astronomical Society, American Chemical Society, American Geological Institute, American Geophysical Union, American Institute of Biological Sciences, American Physical Society, American Psychological Association, American Society of Biological Chemists, American Society of Parasitologists, National Academy of Sciences, Society for the Study of Evolution, Society of Vertebrate Paleontology; 2009.

${ }^{3}$ Perusal of the scientific literature reveals lively and ongoing scientific debates in evolutionary science. See also Eliott Sober's collection of articles addressing conceptual issues in the theory and practice of evolutionary biology, now in an updated and revised third edition (Sober 2007).
}

$2 \%$ compared to $28 \%$ in the USA) had a lower acceptance of evolution.

Much of the literature of the creation-evolution debates focuses on the details and interpretation of scientific data, but we suggest that the deeper issues of the debates concern the nature and practice of science. We contend that a poor understanding of the scientific enterprise fuels to a large degree the opposition to evolution that is prevalent in this country. Misconceptions about science fall roughly into two types: (1) misunderstandings about the basic nature of scientific knowledge (i.e., epistemology; how do we know something in a scientific sense?) and (2) misunderstandings about the scientific process (how do we do science?).

Previous work considers the scientific validity of creationists' arguments and asks whether "creation science" and "intelligent design (ID)" movements are legitimate science (Ruse 1982; Kitcher 1983; Dembski 1998c; Pennock 1999; Massimo 2002; Kitcher 2006). At the heart of this literature is the demarcation or boundary problem. That is, what distinguishes science from non-science? Many authors argue that creationist and intelligent design arguments fail to meet commonly accepted criteria of science, invoking nonnaturalistic explanations and failing to develop testable or falsifiable hypotheses. The contrasts between the methodology and rigor of evolutionary science and various forms of "creationist science" clearly reveal why creationism has no place within the scientific community (see, for example, Young and Strode 2009).

We look at the scientific legitimacy of creationist and intelligent design arguments from a different perspective. Rather than focus on creationism's failure as a scientific endeavor (its poor scientific reasoning, misrepresentation of evolutionary arguments, and lack of testable predictions), we consider how creationists' arguments promote misconceptions about the process and practice of science. As noted above, others have expressed concerns about public misconceptions regarding the nature of science and evolution in particular. Attention, however, has not focused on the manner in which creationism and intelligent design perpetuate such misconceptions. This becomes especially important because debates about teaching evolution in public schools often take place in a context of poor scientific literacy. Students are ill equipped to engage critically in discussions about evolutionary theory and creationism, unless they understand the nature of scientific inquiry. Furthermore, without the ability to recognize scientifically valid arguments and evaluate appropriate evidence, students are prey to pseudoscientific rhetoric.

What constitutes scientific literacy is open to debate, but definitions generally center on levels of scientific knowledge, understanding of scientific processing and reasoning, and ability to understand scientific issues and effectively utilize technology (see for example National Academy of 
Sciences 1996; Miller 2006; Hazen and Trefil 2009a). Even though the U.S. ranks higher than most countries in scientific literacy, the level is still low-only $28 \%$ (Miller 2006). The situation may actually be worse. Hazen and Trefil claim, "Every university in the country has the same dirty little secret: we are all turning out scientific illiterates, students incapable of understanding many of the newspaper items published on the very day of their graduation" (Hazen and Trefil 2009b). Their assessment is that only $22 \%$ of college graduates are fully scientifically literate. Other studies also expose a lack of scientific understanding in the public and among college students, reporting that many students have a poor understanding of the nature of science, failing to differentiate correctly, for example, among facts, proofs, theories, hypotheses, and natural law (Solomon et al. 1996; Jenkins 1997; McComas 1998; Williams 2008). This raises serious concerns about science education in this country because students lacking a clear understanding of the nature of scientific inquiry and an appreciation for what constitutes scientific rigor are likely to be mislead by pseudoscientific arguments (Gross 2006). More specifically, it is cause for concern within the community of biology educators because significant correlations exist between accepting evolution and understanding the nature of science among high school biology teachers and students (Rutledge and Warden 1999, 2000; Trani 2004) and university undergraduates (Lombrozo et al. 2008).

Far too many high school and college biology courses fail to equip students to understand the scientific basis of evolution. Various studies suggest that a substantial percentage of students enter universities ill prepared to critically assess the scientific validity of evolution because many public high school biology teachers avoid teaching evolution in their classes, while many others teach that creationism and ID are valid scientific alternatives to evolution (Berkman et al. 2008; Rutledge and Warden 1999; Aguillard 1999; Moore 2004, 2008; Moore and Kraemer 2005; Bandoli 2008; Moore and Cotner 2009). Religious instruction and high school biology classes shape significantly the attitudes of college students and the public toward the concepts of biological evolution (Bishop and Anderson 1990; Moore et al. 2009; Hokayem and BouJaoude 2008; Cavallo and McCall 2008). Much of this instruction, however, perpetuates misconceptions about evolutionary theory and science (Bandoli 2008; Eick 2000; Bishop and Anderson 1986). Consequently, there is a need to teach about the nature of science and scientific inquiry and to address directly student misconceptions about science (Martin-Hansen 2008; Abd-El-Khalick et al. 1998; Miller 2005).

Religious belief adds another dimension to the way people interact with evolutionary science. It is not enough, therefore, to present only the scientific reasoning support- ing evolution. Additionally, it is important to address worldview issues and epistemological issues (Alters and Nelson 2002; Coburn 2007; Smith 2007). This assessment of science teaching is not new (Fuerst 1984; Moshman 1985; Johnson and Peeples 1987). Polls showing a link between education levels and acceptance of evolution also reveal that the religious beliefs of Americans significantly predict attitudes toward evolutionary theory (Miller 2006; Newport 2009). Indeed, probable reasons for Americans' low acceptance of evolution were identified as the extent of religious fundamentalism, the politicization of science, and the widespread lack of understanding of biological concepts, particularly genetics (Miller 2006). The intersection of religious belief and scientific literacy is particularly intriguing given the long history of creationist attacks on evolution.

As professors of biology, and in the case of one author (FRP) as a member of the Christian clergy, we are often dismayed by the uncritical, yet entrenched, positions of some students. ${ }^{4} \mathrm{~A}$ poor understanding of the nature of science as a way of knowing and an uncritical view of religious authority has polarized major segments of American society, preventing many people from coming to grips with the reality of human evolution. It is essential that our schools educate students about the character of scientific inquiry. We discuss in this article a few of the common misconceptions about scientific knowledge and the process of scientific inquiry, suggest that anti-evolution rhetoric perpetuates these misconceptions, and argue that clarifying these issues for our students will help the American public move toward a more constructive dialogue.

We provide below several examples of the way in which the anti-evolution arguments of creationist and ID advocates propagate misconceptions about science. Our purpose here is not to argue over particular details of evidence but rather to contrast the approaches of the scientific community and creationists toward scientific evidence and to discuss the essence of legitimate scientific inquiries.

\section{Fighting for Authority in the Biology Classroom: What is at Stake}

An understanding of scientific epistemology and methodology is important because it delineates useful boundaries for the creation-evolution debates. Unfortunately, rather than a dialogue that explores what scientists think about the natural world and why, public conversations are riddled with misunderstandings, distortions, and accusations about the scientific validity of evolutionary science and even the motivations of scientists. As we discuss below, there is much at stake for some people - validation of religious and

\footnotetext{
${ }^{4}$ FRP serves as an ordained deacon in the Episcopal Church.
} 
moral convictions - making rivals of science and religious faith. Indeed, some have suggested that the "pervasive teaching of evolution is almost certainly the principal influence affecting the rise of atheism in our scientific community" (Northwest Creation Network 2009). It is perhaps not surprising then that the scientific case for evolution has come under attack (Center for the Renewal of Science and Culture 1998).

The publication of Darwin's theory of evolution by means of natural selection pushed modern science into a new paradigm. Darwin changed the way scientists think of organisms, including humans, and in doing so challenged the Christian worldviews of his day. Even in the twentyfirst century, Darwin is a controversial figure for some. Ernst Mayr's declaration is as true today as it was in 1966: "No other work advertised to the world the emancipation of science from philosophy as blatantly as Darwin's Origin. For this he has not been forgiven to this day..." (Mayr 1966). Previously, humans could be viewed apart from nature, perhaps only a "little lower than the angels," and distinct from other animals. The Darwinian revolution, however, obliges us to see ourselves as part of nature, linked to all organisms, and perhaps only quantitatively rather than qualitatively different from other animals.

This view of human beings conflicts with the religious views of some — but by no means all—Christians (Sager 2008). Historically, opposition to the theory of biological evolution in this country has come mainly from certain Christian sects (Numbers 2006). Biblical interpretation is a fundamental point of difference among Christians. For some Christians, evolutionary explanations for life's origin are at odds with the Biblical account and therefore must be erroneous. Other Christians, however, understand the Biblical account metaphorically and readily accept contemporary scientific accounts as truthful. Consider, for example, the statement of Theodosius Dobzhansky, a Christian and ardent evolutionist:

Does the evolutionary doctrine clash with religious faith? It does not. It is a blunder to mistake the Holy Scriptures for elementary textbooks of astronomy, geology, biology, and anthropology. Only if symbols are construed to mean what they are not intended to mean can there arise imaginary, insoluble conflicts (Dobzhansky 1973a).

Indeed, theologians, clergy, and churchgoers in mainline churches across the country have reconciled human evolution with belief in a transcendent and immanent creator God. ${ }^{5}$

\footnotetext{
${ }^{5}$ See for example the Clergy Letter Project in which clergy from a wide variety of Christian denominations have signed a statement affirming that biological evolution is a "foundational scientific truth" that is not incompatible with religious belief. http://www.butler.edu/ clergyproject/rel_evol_sun.htm, accessed November 18, 2009. See also: Miller (1993), Delio (2008), Haught (2000), and Committee on Science (2005).
}

Evolution, however, particularly in regards to human origins, threatens the belief of many Christians that it is only in and through God that human beings find true purpose and meaning in life. The film Expelled: No Intelligence Allowed, written by and starring Ben Stein, provides a recent example of this position. For his work, Stein received the Phillip E. Johnson Award for Liberty and Truth from Biola University, a Christian institution in Southern California. In his acceptance speech for this award, Stein acknowledged that Darwinism clearly accounts for microevolutionary changes within species, but went on to say that "...when it comes to the big questions - existence, meaning - it adds nothing....Under the Darwinist paradigm, life is meaningless. Under the Darwinist paradigm, we are just mud." ${ }^{\text {"T }}$ The father of a child killed at Columbine High School in 1999 expresses similar views, even suggesting that had the two teenage shooters not been taught evolution they might not have murdered his daughter and the other victims (Brown and Parker 2003). Clearly, for these individuals, the evaluation of the scientific evidence and reasoning is subordinate to evolution's perceived moral implications.

For some people, this "link" between Darwinism and moral decline is very real. ${ }^{7}$ In his book Moral Darwinism, Benjamin Wiker traces the metaphysical foundations of Darwinism and the moral decline in modern society to ancient materialistic philosophies (Wiker 2002). In the foreword to the book, William Dembski writes, “...the motivation behind Darwinism today is its alternative moral and metaphysical vision rather than the promotion of science (p. 11)" and "This book is above all a call to clarity, clarifying the moral structure that God has placed in the world as well as the distorting power of naturalism to undermine that moral structure (p. 13)".

Some Christians and Jews insist that the creation story of Genesis is literally true; that is, God created the earth and all life in six days, and Biblical authority is sufficient to dismiss any scientific arguments to the contrary. ${ }^{8}$ Others, the "old-earth creationists," accept scientific evidence for a four billion-year-old earth, but deny that macroevolutionary changes, such as the transition from reptiles to mammals,

\footnotetext{
${ }^{6}$ Quoted in Newell (2008).

${ }^{7}$ See for example Morris (1982) and Ham (2002); "The result of believing evolution" Living Word Bible Church web site: http:/www. lwbc.co.uk/Genesis/results\%20of\%20believing\%20evolution.htm, accessed November 27, 2009.

${ }^{8}$ Selected websites and organizations promoting "young earth" creationism: Answers in Genesis (http://www.answersingenesis.org/); Creation Ministries International (they publish Creation Magazine, and the Journal of Creation; http://creationontheweb.com/); Creation Research Society (they publish Creation Research Society Quarterly (http://www.creationresearch.org/); Creation Moments (http://www. creationmoments.com/); Institute for Creation Research (they publish Acts \& Facts magazine; http://www.icr.org/).
} 
are possible purely by natural means. ${ }^{9}$ Common among Christian creationists, however, is a theism that portrays God actively governing natural processes. Both groups insist, for example, that the appearance of the major groups of organisms is dependent upon the action of God.

Additionally, creationists in both camps generally interpret Biblical passages as factual statements about human origins, human nature, and human history (Meyer 2000). Consequently, defending the factual accuracy of the Bible becomes paramount. If the Bible is wrong about our origins, for example, then it cannot be the word of God as previously understood and, therefore, may be wrong about everything else, becoming merely a collection of myths and fables without authority on spiritual matters. For some Christians then, the Bible must be the ultimate authority even in matters of science. Energized by religious conviction, creationists battle the secular scientific community, with the vindication of their faith and their God at stake.

Also at stake is the character of scientific explanations. Scientific inquiry employs a "methodological naturalism" which seeks natural explanations for natural phenomena. The scientific community maintains that there is no basis for testing a non-naturalistic hypothesis against the reality of the natural world; therefore, the naturalistic limitation must remain a criterion for scientific explanations. This means, of course, that the scientific community does not entertain the action of God as a viable hypothesis for any biological process. Some anti-evolutionists, however, seek to broaden the scope of "science" to include the possibility of non-naturalistic explanations for natural phenomena (Meyer 1994b, 1996, 2000). ID proponents, for example, want to bring to the table the idea that "certain features of the universe and living things are best explained by an intelligent cause" (Intelligent Design and Evolution Awareness Center 2004). ${ }^{10}$ The intelligent cause could conceivably be a material entity (for example alien intelligence), ${ }^{11}$ which would then be subject to scientific inquiry. Clearly, this is not seriously considered by most supporters of ID who instead link the intelligent designer with the Judeo-Christian God. ${ }^{12}$ They, therefore, reject the

\footnotetext{
${ }^{9}$ Genesis Proclaimed Association (http://www.genesisproclaimed.org/ home.asp); Reasons to Believe (http://www.reasons.org/).

${ }^{10}$ Selected websites and organizations promoting Intelligent Design: Access Research Network (http://www.arn.org/); Design Inference Website (http://www.designinference.com/); Discovery Institute, Center for Science \& Culture (http://www.discovery.org/csc/); IDEA Center (Intelligent Design and Evolution Awareness Center; http:// www.ideacenter.org/); Intelligent Design Network, Inc. (http://www. intelligentdesignnetwork.org/index.htm); The International Society for Complexity, Information, and Design (ISCID; http://www.iscid.org/); Uncommon Descent (http://www.iscid.org/).

${ }^{11}$ This was suggested as a possibility in Dembski (1998).

12 Dembski, himself, makes this clear in a number of writings. See for example Dembski (1999).
}

rules of methodological naturalism, insisting that scientific evidence does in fact point to an "intelligent designer." They are fighting for authority over science by challenging evolutionary theory, questioning the science, discounting much of the evidence for biological evolution as speculation and "just-so stories," and criticizing evolutionists for a supposed unthinking allegiance to naturalistic philosophy (Behe 2006; Johnson 1997b).

It is important to understand that the creation-evolution debates are about much more than merely the interpretation of scientific data. While the scientific community focuses on empirical evidence, political forces drive school boards and the misconceptions about science that creationist arguments perpetuate go largely unchallenged in this context. Consequently, it is particularly crucial to understand motivations, religious biases, and hidden agendas in these debates. There is much at stake in the creation-evolution debates, since legitimizing consideration of a "God hypothesis" within the scientific enterprise redefines the essential nature of science. Given this backdrop to the debates over the teaching of evolution in public schools, it is imperative that biologists explain the nature of scientific inquiry clearly and accurately. ${ }^{13}$

\section{Misunderstandings About the Basic Nature of Scientific Knowledge}

\section{Accusations of Metaphysical Bias}

The scientific community seeks testable, natural explanations for natural phenomena. "Methodological naturalism" is the epistemological or procedural approach that guides scientific inquiry. Some Christians see methodological naturalism as weakness, arguing that it ignores the possibility of God's action, a fundamental conviction of their faith. ${ }^{14}$ ID proponents question the reasonableness of self-imposed naturalistic restrictions, claiming that methodological naturalism is "philosophically inadequate" because

\footnotetext{
${ }^{13}$ We present in this paper a view of the nature and practice of science that, while commonly held by practicing scientists, is certainly not the only view. For similar views to our own, see the following: American Association for the Advancement of Science (1993), National Science Teachers Association (1997), National Academy of Sciences (1998), and McComas et al. (1998). For introductions to the philosophy of science and discussions of various views of science, see Laudan (1990), Mayo (1996), Ladyman (2001), Godfrey-Smith (2003), DeWitt R (2004), French (2007).

${ }^{14}$ See for example Creation-wiki entry, Evolution's materialism or naturalism denies a role for God. http://creationwiki.org/Evolution's materialism_or_naturalism_denies_a role_for_God, accessed March 25, 2010; Johnson (1999).
} 
it restricts the search for truth. Consider the following statements by proponents of ID.

Methodological naturalism, the view that for the sake of science, scientific explanation ought never exceed undirected natural causes, is to be rejected because it stifles inquiry. Nothing is gained by pretending science can get along without intelligent causes. Rather, because intelligent causes are empirically detectable, science must ever remain open to evidence of their activity (Dembski 1998d).

Indeed, the most important reason to question methodological naturalism is not that it undermines the claims of religion; the best reason to question the doctrine is that it limits the prerogatives of science. Methodological naturalism is not so much irreligious, as irrational. Hyperbole aside, strict naturalism functions (at least within origins research) to close off legitimate lines of inquiry and avenues of potential explanation. It, therefore, limits the ability of scientists to pursue the truth wherever, and perhaps, to Whomever, it might lead (Meyer 1994a).

Some philosophers are sympathetic to the claims of a naturalistic bias in the sciences. Robert Delfino, for example, argues that although methodological naturalism is distinct from ontological naturalism "it still adds a type of metaphysical bias to science" (Delfino 2007; see also Delfino 2000). He argues that replacing methodological naturalism with a metaphysically neutral epistemology will make science more rational and objective. Alvin Plantinga goes so far as to say that naturalism is not even defensible from an evolutionary perspective (Plantinga 2000, 2008).

Behind the criticisms of creationists and ID advocates, however, is the view that ontological naturalism (the position that the material universe is all that exists) materialism - underlies methodological naturalism (Johnson 1990, 1997a, 1999; Dembski 1996). Ontological (or metaphysical) naturalism denies the existence of the supernatural, of God, a position that creationists resolutely denounce. Creationists may present a view of science in language that appears to champion a rigorous evidencebased methodology, ${ }^{15}$ but closer inspection reveals they conflate methodological naturalism with philosophical materialism. For example, science resource material provided by the Creation-Science Research Center in San

\footnotetext{
${ }^{15}$ See for example, the discussion of the scientific method in A Science Kit About Science (2003), made available on-line as science resource material for homeschooled children by The Parent Company (http://www.parentcompany.com/science_kit/ sk-1.htm, accessed March 18, 2010). See also Baumgardner (2008).
}

Diego, California for homeschooled children says, "Unfortunately, those who today control science and education have adopted a false definition of science. They teach that science by definition requires scientists to believe something. They teach that scientists must believe that they are investigating a universe which is totally materialistic and that everything in it is a product solely of time, chance and naturalistic physical and biological evolution" (A Science Kit About Science 2003). John Baumgardner, writing for the Institute for Creation Research, argues that philosophical naturalism undermines good science, stating, "The scientific method fails to yield an accurate representation of the world, not because of the method, but because of those who are attempting to apply it. The method fails when scientists themselves, usually collectively, allow their own biases and personal preferences to shortcircuit [sic] the hypothesis-testing part of the process" (Baumgardner 2008). The perceived threat of ontological naturalism is also a major point of argument between intelligent design advocates and evolutionists. "Intelligent Design entails that naturalism in all forms be rejected. Metaphysical naturalism, the view that undirected natural causes wholly govern the world, is to be rejected because it is false" (Dembski 1998d). "As Christians we know naturalism is false. Nature is not self-sufficient, God created nature as well as any laws by which nature operates" (Dembski 1998b).

ID advocates downplay any religious motivation and contend that scientific reasoning shapes the ID position that certain patterns of biological complexity ("specified complexity" in the form of "irreducibly complex" cellular systems or in the information content of DNA) cannot arise by purely naturalistic means (Behe 1996, 2007; Dembski 1998a; Meyer 2004a). Leaders of the ID movement insist that ID is a scientific argument against the reigning neoDarwinist paradigm and is not a creationist movement with a religious agenda (Intelligent Design and Evolution Awareness Center 2009). A considerable body of evidence, however, speaks to the contrary (Forrest and Gross 2004; Kitzmiller 2005). Some ID advocates, for example, argue that Christian theism is under attack and suggest that a "theistic science" is needed to counter the naturalistic presuppositions that underlie all evolutionary scenarios (Plantinga 1991, 1997; Johnson 1993, 1998; Mooreland 1994a; Gish 1995). Certainly, many Biblical creationists ally themselves with the ID movement, arguing that the intelligent agent who imparts complex, integrated order and informational content to living systems is God in the JudeoChristian sense.

Of course, one cannot dismiss an evidence-based criticism of evolution simply because religious convictions motivated that criticism. Ultimately, we must judge a scientific argument, whether in support or opposition to an evolutionary scenario, based upon available evidence and not upon the ideologies of 
the debaters. The central questions are how we can best come to know in a reliable and rigorous way the nature of the universe in which we exist and whether there is room for the supernatural in scientific explanations. Scientists disregard non-naturalistic explanations because they cannot be defended by testable, verifiable evidence.

Accusations of bias and close-mindedness, however, call into question the objectivity of evolutionists in the public consciousness. Some critics of evolution have even suggested that scientists have conspired to hide known weaknesses in evolutionary theory. Jonathan Wells' anti-evolution book, Icons of Evolution, follows this line of argument, claiming that long-accepted scientific explanations are "false or misleading." " There is a sentiment that evolutionists are unwilling to entertain alternative arguments, that they fear academic freedom (Roth 1978; Thomas 2002; Luskin 2008b; Brown and Brown 2008; Discovery Institute 2009).

As evidence of bias, creationists often quote evolutionists, such as Richard Dawkins, who put forward a strictly materialist view: "Darwin made it possible to be an intellectually fulfilled atheist (Dawkins 1986)." Such a polarized view - evolution and atheism versus supernatural creation and theism - fails to appreciate the fact that a great many evolutionary scientists as well as Christian theologians do not fall into either of these camps. Furthermore, it makes science less about a quest for knowledge and understanding of the physical universe in which we live and more an apologetic weapon in defense of an ideology.

When critics of evolution follow this line of argument, they perpetuate a misconception about the nature and scope of scientific inquiry. Their accusation of bias carries weight only if one accepts the premise that scientific inquiry should be open to all lines of evidence, including nonnaturalistic arguments. While consideration of all possible explanations seems fair, it mistakenly asks science to move beyond its proper realm of authority - testable, verifiable explanations in the realm of matter and energy.

Misconception: Good science must consider all possible explanations.

Failure to Respect the Limits of Science

Creationists and intelligent design proponents in particular argue that the diversity of life on earth is best accounted for by the action of an intelligent force (See for example: Moreland 1994b). They argue that the improbability of naturalistic scenarios for evolution precludes biological evolution as a viable hypothesis (see for example Behe 1996; Dembski 1998a). They point to the anthropic principle - the idea that fundamental physical constants of the universe must be as

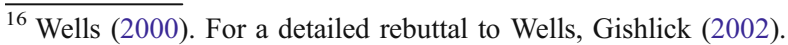

they are for life to exist - as evidence that the origins of the universe requires an intelligent designer (see for example Gonzales and Richards 2004). They interpret scientific data as evidence against evolution and as evidence in favor of creationism (see for example Sharp 1994; Brown 1995; Ross 2006). Although claiming that these arguments stand on scientific merit alone, it is clear that religious interests motivate the creationist and intelligent design movement (Dembski 1998a). Certainly, the subtext picked up by lay audiences is that the intelligent force is a supernatural being. Furthermore, as already noted, they accuse the scientific community of attempting to suppress these ideas by defining science in such a way to exclude them.

These arguments by creationist and intelligent design advocates contribute to the misunderstanding of the nature of science by the public. Their insistence upon equal time in classrooms to present critiques against evolution as well as alternative hypotheses suggests that their arguments are in fact legitimate scientific alternatives. The religious subtext implies that science can in fact address metaphysical questions.

\section{Misconception: Science addresses questions about the meaning of life.}

Another issue pertaining to the limits of science is whether certain moral positions are inherently linked to scientific data. One study, for example, revealed that even some collegeeducated persons identified as "strong evolutionists" held that acceptance of evolution promoted "increased selfishness and racism, decreased spirituality, and a decreased sense of purpose and self-determination" (Alters and Nelson 2002; Brem et al. 2003). As noted earlier, many anti-evolutionists believe that the materialistic bias of science and the theory of evolution in particular contribute to moral decline (see also Bergman 1999a, 2001; Hall 2005).

\section{Misconception: Science promotes particular social values.}

This misconception focuses especially on evolutionary science, although one can also see the same issue raised regarding scientific arguments about climate change. The reality is that scientific data, rightly or wrongly, have been used to reinforce a variety of political and social perspectives. The idea that evolution contributes to immorality and social evils is not based on an objective consideration of the evidence (see for example, Isaak 2006). Indeed, instead of undermining ethical behavior, according to some scientists, evolution provides a basis for ethical behavior (see for example Ayala 1987, 2007). Nonetheless, this misconception persists and research suggests that educators should address directly these prejudices about science since these influence student responses to the teaching of evolution (Eick 2000; Abd-El-Khalick et al. 1998; Sinatra et al. 2003; Ingram and Nelson 2006; Hermann 2008). 
Examining the Nature of Science

\section{Defending Methodological Naturalism}

The scientific community defends its naturalistic approach as the appropriate method by which to learn about the natural world. Contrary to the fears of some critics that science promotes ontological naturalism, science simply looks for natural explanations for natural phenomena, employing a "methodological naturalism." While many scientists adhere to naturalistic or materialist philosophies, drawing upon an understanding of science to defend philosophical naturalism (Forrest 2000), science itself does not demand that its practitioners hold such positions. Scientific data, strictly interpreted, describe the natural realm-patterns and processes. What a person infers from those data about the origin or meaning of our existence has no consequence to how the universe actually is. This is true whether you extract religious meaning from biological complexity, as ID advocates do, or whether you extract an atheistic philosophy from evolutionary theory. Physical reality is what it is, and science at its best offers descriptions of that reality. Scientific methodology is limited to finding explanations for natural phenomena in naturalistic terms.

Some philosophers of science argue that the epistemology of science has no privileged status, that there are no criteria by which to demarcate scientific knowledge from religious, historical, or philosophical knowledge (Laudan 1996). Inference to the best explanation, some argue, may lead to non-naturalistic hypotheses (Meyer 1999). Consequently, there is a desire among many critics of evolutionary theory to rewrite the rules of doing science, to do away with methodological naturalism-a move that would thereby accommodate theories of intelligent design or creation under the umbrella of "science."

Practicing scientists, however, have no use for such theorizing since no one has presented a reliable method of testing non-naturalistic hypotheses - there is no practical or heuristic value in this approach. Furthermore, despite claims to the contrary, neither William Dembski's criterion of specified complexity (Dembski 1998a) nor Michael Behe's notion of irreducible complexity (Behe 1996) provides convincing evidence of the need for an intelligent agent-these ideas have not borne fruit (Wilkins and Elsberry 2001; Shanks and Joplin 1999).

The ID approach has not led to a successful modeling of natural processes. From a pragmatic point of view, nonnaturalistic hypotheses are simply poor science.

\section{Establishing Limits of Science}

Creationists clearly operate from a teleological worldview and often claim that evolutionary theory eliminates purpose in human existence. The misconception propagated is subtle, but nonetheless detrimental to a proper understanding of science in modern culture. Science focuses on understanding the nature and behavior of the universe and consequently does impact the viability of various worldviews. Furthermore, as scientific understanding advances, questions previously thought outside the bounds of science become subject to scientific inquiry. For example, 200 years ago, a worldview in which God specially created human beings was a viable, rational worldview. People today still hold this worldview. A 2004 Gallop poll indicated that $45 \%$ of Americans believe that "God created human beings pretty much in their present form at one time within the last 10,000 years or so" (National Center for Science Education 2004). Research over the past two hundred years, however, has made belief in a "young earth" and/or the independent creation of humans scientifically untenable. The plain sense of the data says that the earth is approximately 4.6 billion years old and that humans have a genetic relationship to all other species on earth, with a particularly close connection to chimpanzees. Interpretations of the first chapters of Genesis must either account for this information or dismiss the scientific enterprise as a whole. Clearly, scientific understanding affects the viability of particular worldviews. Nevertheless, one can argue that science shot down a particular worldview, but in the final analysis has not resolved the questions: "Is there purpose in our existence?" or "Does a God exist?"

The scientific community remains firmly committed to methodological naturalism as the appropriate approach to any investigation of the natural world. One must ask, however, whether this allegiance to natural explanation precludes certain questions from the realm of science. Stephen Gould, for example, argued this in his book, Rock of Ages, that religion and science possess different and distinct realms of authority, what he referred to as "nonoverlapping magisteria" (Gould 1999). This view leaves room for different ways of knowing and suggests that science must recognize its own limitations.

Our failure to discern a universal good does not record any lack of insight or ingenuity, but merely demonstrates that nature contains no moral messages framed in human terms. Morality is a subject for philosophers, theologians, students of the humanities, indeed for all thinking people. The answers will not be read passively from nature; they do not, and cannot, arise from the data of science. The factual state of the world does not teach us how we, with our powers for good and evil, should alter or preserve it in the most ethical manner (Gould 1982).

The National Academy of Science, in the book Science and Creationism, accepts Gould's delineation of distinct scientific and religious domains (National Academy of Sciences 1999). Others, however, have criticized this distinction, arguing that the metaphysical claim that God 
exists can be treated as a scientific hypothesis (see for example Pigliucci 1998; Forrest 2000; Dawkins 2006). We suggest a narrower view of science in which science describes the nature and behavior of the universe, but makes no claims on questions pertaining to purposes or ultimate causes. Science itself only tells us directly about physical reality. More specifically, science focuses on testable questions about matter and energy. Scientists like Richard Dawkins, for example, may infer from their scientific understanding of the universe that God does not exist; indeed, one may argue this position with great conviction (Dawkins 2006), but science has not proven the nonexistence of God. The authority of science may bolster a philosophical or religious position, but our belief systems do not rest only upon scientific data. Despite claims that science demonstrates God does not exist (Stenger 2007, 2009), we contend that this lies beyond the boundaries of science since such inferences are not testable. Acknowledging this of course does not preclude scientific understanding to be foundational in any argument for or against a particular worldview.

Science is most appropriately a philosophically neutral way of knowing about our universe. Science is an effective, practical, and reliable way of knowing about the physical universe, but we make a mistake when we ask our science to give us more than descriptions of the structure, behavior, and function of the universe. If we are careful to separate our religious and philosophical biases from scientific facts, then we allow science to function as a tool for investigating nature, providing descriptions and explanations of natural phenomena, generating a model of physical reality that has credibility within Christian, Jewish, Muslim, Hindu, Buddhist, and atheist circles. While biology-or science in general-cannot claim to answer certain questions definitively, it can delimit which arguments, moral pronouncements, or biblical interpretations are tenable.

\section{Misunderstandings About the Scientific Process}

Creationists and ID proponents challenge the credibility of evolutionists and the validity of evolutionary science. In doing so, they perpetuate misconceptions about the scientific enterprise. We present some of the accusations made against evolution and show how these challenges present a distorted picture of the practice of science.

\section{Accusations of a Lack of Professional Integrity}

As noted earlier, a central concern among anti-evolutionists is that a naturalistic bias permeates modern science. Referring to evolutionists, Henry Morris says, "Often they are downright bigoted, especially when asked to consider a concept outside their naturalistic worldview" (Morris 1998). Phillip Johnson suggests that evolutionists have invested a great deal in naturalism. "The prestige of the scientific establishment, and of the intellectual class in general, is heavily committed to the proposition that evolution - in the blind watchmaker senseis either a fact, or a theory so well supported by evidence that only ignorant or thoroughly unreasonable people refuse to believe it. If the scientists ever had to retreat on this issue, the cultural consequences could be significant. Persons who now have a prestigious status as cultural authorities would be discredited, and the political and moral positions they have advocated might be discredited with them" (Johnson 1996).

Creationists and ID proponents allege censorship and the unwillingness of peer-reviewed scientific journals to give alternative views to neo-Darwinian evolution a fair hearing (Luskin 2008b, 2009a; Morris 2004; Dembski 2006; Wells 2006a). In 2004, for example, William Dembski, a leading ID proponent, wrote, "In the current intellectual climate it is impossible to get a paper published in the peer-reviewed biological literature that explicitly affirms intelligent design or explicitly denies Darwinian and other forms of naturalistic evolution. Doubting Darwinian orthodoxy is comparable to opposing the party line of a Stalinist regime" (Dembski 2004). Such claims appear unwarranted and sidestep the real issue, which is the scientific merit of papers submitted (Flank 1995; Isaak 2004). ID advocate Stephen Meyer received notoriety when a refereed scientific journal published an article in which he argued that no current materialistic theory of evolution could account for the origin of the information necessary to build the novel animal forms appearing during the Cambrian explosion (Meyer 2004b). The journal subsequently denounced the actions of the editor involved in approving publication, leading to claims of bias by the ID community. Careful review of the paper, however, substantiated the journal's position that the paper lacked scientific merit. ${ }^{17}$ Other claims of prejudice against creationists and critics of evolution have surfaced over the years, including, for example, the case of Guillermo Gonzalez, an astrophysicist who was denied tenure allegedly for his allegiance to ID (Bergman 2008; Discovery Institute 2008). The evidence available indicates this was not the case; rather the scientific merit and trajectory of his productivity were at issue (Lebo 2008; Expelled Exposed). ${ }^{18}$

To imply that the scientific community behaves in hostile, petty, and vindictive ways toward dissenters because of a philosophical bias toward naturalism calls

\footnotetext{
${ }^{17}$ See the following for rebuttals to Meyer's paper and discussion of the controversy: Statement from the Council of the Biological Society of Washington: (http://web.archive.org/web/20070926214521/http:/www. biolsocwash.org/id_statement.html, Accessed December); Giles (2004), Gishlick et al. (2004), Elsberry (2004), Weitzel (2005), Mooney (2005), Discovery Institute (2005a), Luskin (2006b).

${ }^{18}$ Statement from Iowa State University President Gregory Geoffroy. Iowa State University News Service; 2007. http://www.iastate.edu/ $\sim$ nscentral/news/2007/jun/statement.shtml, Accessed December 4, 2009.
} 
into question the integrity of scientists. Such charges tacitly promote an image of the good scientist as an objective, dispassionate seeker of truth. This caricature shifts the focus away from critical analyses of evidence and fails to appreciate the checks and balances inherent in the communal nature of the scientific enterprise.

Misconception: Each scientist must be a perfect, dispassionate seeker of truth for the enterprise as a whole to be valid.

Accusations of bias fail to appreciate the self-correcting character of the scientific community (Longino 1990; Harding 1991; Solomon 2001). In portraying evolutionary scientists as prejudiced, creationists imply that only they are evaluating evidence objectively. Not only is this illogical, but creationists are building a straw man out of the myth of the detached, hyper-analytical scientist. When compared to this caricature, it is not surprising to find some scientists inadequate. Social and human factors play a role in the scientific enterprise, but this does not invalidate scientific conclusions. This is because science is a communal activity.

Scientific integrity is paramount within the scientific community. We strive for honesty and objectivity when evaluating and interpreting data, but in reality, we are not always as objective as we like to think-personal beliefs often influence our interpretation of data (see for example Broad and Wade 1985; Collins and Pinch 1998; Silverberg 2007). This is acknowledged by scientists:

Scientists, being as a rule more or less human beings, passionately stick up for their ideas, their pet theories (Eldredge 1995).

It is, in fact, a common fantasy, promulgated mostly by the scientific profession itself, that in the search for objective truth, data dictate conclusions. If this were the case, then each scientist faced with the same data would necessarily reach the same conclusion. But as we've seen earlier and will see again and again, frequently this does not happen. Data are just as often molded to fit preferred conclusions (Lewin 1997).

But our ways of learning about the world are strongly influenced by the social preconceptions and biased modes of thinking that each scientist must apply to any problem. The stereotype of a fully rational and objective 'scientific method,' with individual scientists as logical (and interchangeable) robots, is selfserving mythology (Gould 1994).

Some scientists, for example, saw religious dogma embedded in Big Bang cosmology and fought to hold on to a steady-state universe (Kragh 1996), and some committed young-earth creationists continue to probe for chinks in the scientific armor of Big Bang cosmology, refusing to concede to a thirteen billion-year-old universe (Lisle 2009).

The development of scientific explanations is certainly not without its share of false leads and blind alleys. Scientists invest their intellectual reputation in particular hypotheses and become emotionally attached to a specific way of thinking (Goldstein and Goldstein 1984; Gratzer 2000; Thagard 2002, 2004; Rothchild 2006). Even after new evidence has slain an old hypothesis, those ideas may decompose slowly. Christian theologians equally invest themselves in particular doctrines and dogma. The question is not whether individual scientists or theologians are more trustworthy or less biased than the other; rather the important question is whether there are strategies in place to deal with differing opinions and personal biases, strategies for course correction.

Scientific communities look toward new data to resolve ambiguities - science is self-correcting. Whatever blinders we wear and whatever biases we carry are personal. Others may share them, but they are nevertheless individual prejudices. Scientific hypotheses, however, rise or fall on evidence interpreted and evaluated by a community. Consequently, because individual interpretations compete for acceptance, mistaken ideas eventually fall by the wayside. When scientists dispute particular data or hypotheses, the resolution is to go to nature, collect more data and conduct experiments - to ask, "What is reality?" This approach, of course, requires that we construct hypotheses that are testable in the natural world.

The scientific community tests and retests its explanations, challenging all assumptions, eventually eliminating biases and mistaken understandings. Scientists proceed in their work confident that physical reality is knowable and trusting that our understanding of that reality is continually refined. We push forward each generation, collecting and analyzing new data, fine-tuning or replacing old concepts with more accurate and useful ones - each generation of scientists climbing higher on the backs of its predecessors to see farther and more clearly.

\section{Accusations of Unsubstantiated and Uncritical Science}

Critics of evolutionary theory question not only the integrity of the scientific enterprise but also the rigor of practicing scientists. They argue that unsubstantiated claims, uncritical interpretations, and speculative conclusions litter the scientific literature.

A frequent argument against macroevolution is that there is insufficient evidence to warrant the conclusions made about major evolutionary transitions - that transitional links and intermediate forms do not exist in the fossil record and the proposed mechanisms are incapable of effecting such changes. Creationists and ID proponents claim that allegiance to a materialistic worldview drives evolutionary theory more than any established biological evidence. This 
is the premise of a seminal work in the ID movement, Phillip Johnson's Darwin on Trial (Johnson 1993). Jonathan Wells claims that an examination of such disciplines as paleontology, genetics, and embryology reveals a scantiness of evidence for Darwinian evolutionary theory. Darwinism, according to Wells, is waging a losing battle against ID. "Darwinism will lose," he says, "most importantly, because of the evidence. Even though Darwinists have had almost 150 years to find some, the evidence for their view is underwhelming, at best" (Wells 2006b). Consider also the words of Kyle Butt, "Evolutionists understand that if students are given the opportunity to look at evolution with an open mind, study it carefully, and consider it critically, the theory collapses under its own, insupportable weight" (Butt 2008).

Creationist and ID proponents often point to a supposed lack of transitional forms in the fossil record. ${ }^{19}$ When transitional forms are uncovered, creationists question the interpretation of data. A case in point is the discovery of a tetrapod-like fish, Tiktaalik roseae, which appears transitional between fishes and amphibians (Daeschler et al. 2006; Shubin et al. 2006; Ahlberg and Clack 2006). Further analysis of the cranial endoskeleton provided additional evidence of the transitional status of Tiktaalik (Downs et al. 2008).

Like defense lawyers trying to instill doubt in the minds of jurors, creationist critics tend to avoid the difficult and meticulous analysis required in interpreting paleontological data. Instead, they confine themselves to raising doubts. This strategy attempts to discredit mainstream science, alleging that evolutionary scenarios are distorted or inaccurate pictures of physical reality.

For example, Casey Luskin and Logan Gage, of the Discovery Institute's Center for Science and Culture (a policy institute which advocates the teaching of ID in schools), downplay the importance of Tiktaalik, stating that plausible transitional forms are exceptions and not the rule. They then suggest that Tiktaalik is not even convincing as a transitional form. Ignoring tetrapod-like characters like sturdy wrist bones, a flattened skull, flexible neck, and thick ribs, they concentrate on the superficial appearance of one feature, the fin. "Tiktaalik has a completely finlike fin and does virtually nothing to document the key aspect of the alleged fish to amphibian transition, the transformation of fins into feet" (Luskin 2008d; see also Luskin 2006a). "[S]cientists have yet to uncover a scrap of evidence to suggest that they functioned as anything but common fins, which renders their transitional status somewhat specious, to say the least" (Luskin and Gage 2008). Luskin has continued to argue against the transitional status of Tiktaalik (Luskin 2008c, 2009).

\footnotetext{
${ }^{19}$ There are many examples of this argument, from ID proponents and creationists. See for example Brown (1995).
}

Kent and Marti Rieske, of Bible Life Ministries, are also fixated on Tiktaalik's fin, and resort to ridicule in place of analysis:

The claim that the stubby little fossil fins are "limblike" is a real hoot. The fish doesn't even have fins as large as expected for its size. The scientists are claiming the fish walked around on the ground out of water and breathing air. This is pure make believe speculation. No evidence exists that the fish is anything more than just another species.

The excitement about the Tiktaalik fossil is puzzling. Modern-day seals have fins and waddle around on the ground. Modern-day catfish have fins and walk around on the ground. Catfish can live out of water for a long time without dying. Tiktaalik does not provide any support for evolution (Reiske and Reiske 2009).

The superficial analyses by anti-evolutionists have been criticized for their lack of merit. ${ }^{20} \mathrm{~A}$ closer look at creationist and ID assertions reveals misconceptions about the scientific process. On the surface, much of the debate between evolutionists and creationists appears to concern only the interpretation of data. Are the data sufficient? What interpretations of the data are valid? These questions certainly occupy the attention of scientists, but embedded in creationist challenges to evolutionary explanations and scenarios are misconceptions about the nature and use of scientific evidence. The types of critiques presented above imply that science is about proofs, that scientific credibility requires absolute certainty. Implicit in these criticisms is the idea that scientists should consider any conceivable explanation of a set of data, regardless of how unlikely, and until they can eliminate all but one with certainty, their conclusions are suspect. This misunderstanding of the process of science leads to the commonly heard refrain, "It's only a theory" - nothing more than an unproven idea. Such critiques perpetuate several misconceptions about the process of science.

Misconception: Scientific theories are only opinions.

Misconception: Science provides absolute proof.

Misconception: Unanswered questions undermine a theory.

\footnotetext{
$\overline{{ }^{20} \text { For rebuttals }}$ to Tiktaalik's critics, see: blogs by PZ Myers ("The Discovery Institute on Tiktaalik: Pharyngula," posted April 7, 2006; http:// scienceblogs.com/pharyngula/2006/04/the_discovery_institute_on_tik. php, accessed December 14, 2009); Jason Rall ("New technologies show Panderichthys and Tiktaalik on the way to living on land" posted September 30, 2008; http://nondiscovery.wordpress.com/2008/09/30/pan derichthys-and-tiktaalik/, accessed December 14, 2009); and Martin Brazeau ("AiG tries to respond to Tiktaalik" posted April 7, 2006; http://lancelet.blogspot.com/2006/04/aig-tries-to-respond-to-tiktaalik.html, accessed December 14, 2009). See also Prothero (2007), Shubin (2008), and Coyne (2009).
} 


\section{Examining the Scientific Process}

Without a clear understanding of the character of scientific evidence and the scientific process, debates between evolutionists and their critics will remain frustrating and unproductive. We discuss below some aspects of science, which speak to these misconceptions.

\section{The Partial and Provisional Nature of Science}

The scientific community harbors no illusions that it has successfully deciphered all the complexities of the material universe, or can ever reach absolute certainty. We recognize that our understanding remains incomplete. In many ways, the universe is even more mysterious now than it was 100 years ago - new experiments and new observations generate more and deeper questions about the nature of our universe. Nevertheless, a partial and imperfect knowledge of physical reality at present does not mean we are incapable of furthering that knowledge.

The very nature of the scientific enterprise makes scientific explanations subject to the "Big-Tobacco Gambit." For years, despite accumulating evidence linking lung cancer to cigarette smoking, tobacco companies continued to claim lack of absolute proof. An individual who believes that evolution must be false may similarly support his or her position by pointing to the inability of biologists to prove a particular evolutionary scenario. In his book, No Free Lunch: Why Biological Complexity Cannot Be Purchased without Intelligence, William Dembski argues that evolutionary explanations lack sufficient causal detail to address questions of macroevolutionary change, dismissing these explanations as "Darwinian just-so stories [which] are no more enlightening than Rudyard Kipling's original just-so stories about how the elephant got its trunk or the giraffe its neck" (Dembski 2002).

Skepticism fuels the scientific process - questioning the validity of a particular interpretation of data is an essential part of doing science. To be of value to the scientific community, however, criticisms must rest upon an examination of the evidence. Simply voicing disbelief in the conclusions of a scientific investigation does nothing to advance or refine our understanding of natural processes. The discovery of Tiktaalik does not resolve all our questions about the evolution of limb development-scientists understand that new findings often raise new questions - but to simply deny the significance of the transitional aspects of Tiktaalik is neither scientifically useful nor demonstrative of sincere scientific skepticism. Furthermore, biological evolution is based upon a very large body of evidence, and criticisms of evolution must therefore also consider the large body of evidence, which is ignored. ${ }^{21}$

\footnotetext{
${ }^{21}$ For a discussion of the transitional fossils supporting biological evolution, see TalkOrigins (http://www.talkorigins.org/indexcc/CC/ CC200.html, accessed July 15, 2009).
}

The assertion by some creationists that science has failed to prove a particular evolutionary scenario fails to appreciate the nature of scientific knowledge. Scientific understanding of the evolution of the vertebrate eye, for example, may be incomplete currently; indeed, scientific knowledge in some sense is always incomplete or provisional. Nevertheless, there exists sufficient evidence to support with confidence-beyond a reasonable doubt - that the vertebrate eye has indeed evolved (Lamb et al. 2007). Scientists seek natural explanations for phenomena observed in nature. Absolute proof for those explanations is neither required nor expected. It is enough that the accumulating evidence from many lines of inquiry leads to the reasonable certainty that evolution has occurred. Despite the media hype, creationist's claims to the contrary have not withstood scientific scrutiny - they are not serious threats to evolutionary theory. Creationists mischaracterize science when they suggest we should expect absolute certainty from scientists and are disingenuous when dismissing the great body of evidence for evolution on this basis.

2. Empirical Evidence, Falsification, and Emerging Confidence

Scientific statements about the nature of physical reality are statements of probability. At the core of scientific theories are principles or laws about the properties and behavior of matter and energy for which we have great confidence. Different scientists around the world have tested these ideas independently and repeatedly, and they consistently and accurately predict and confirm the same experimental outcomes. Consequently, there emerges a conviction that such theories do in fact describe some aspect of an underlying physical reality. Ideas about why matter behaves as it does may be modified, expanded, or refined, but we remain convinced that the patterns observed reflect real events.

Other less well-documented hypotheses about matter and energy must await additional empirical support before acceptance as scientific reality. Scientists will poke, test, and cultivate these hypotheses in an effort to answer some question about natural phenomena, aborting some and holding on to others. This is an exciting process. There is an eager anticipation of discovering some new feature of nature. This realm of science is not one of certainty; rather it is a place of creativity. It is understandable then that the humanness of the scientific process is most apparent hereegos bruised, biases surfaced, clarity threatened - but it is from this crucible that viable theories emerge. It is important not to conflate this aspect of science with the core of scientific understanding. At the frontier of science, rigorous testing decides which new ideas may enter the core. 
Physical stresses remodel the bones of our skeleton, modifying and strengthening them. Core understandings in science are also dynamic, adjusting as new discoveries enrich and deepen our knowledge. Rarely do the stresses of new information shatter the skeletal system. Despite suggestions by ID proponents that an evolution-shattering paradigm shift is underway (Sharp 1994; Moreland 1994b; Brand 1997; Dembski 1998c; Brewer 2001; Slack 2007; Hasker 2009), evolution theory appears as robust as ever.

Creationists have attacked the evolutionary core of biology for decades. One strategy has been to quote evolutionists (often out of context) to suggest skepticism about the evolutionary paradigm and even to insinuate an imminent collapse of evolution theory (Pieret 2006; Morris 1997; Jones 2009). Often, critics of evolutionary theory find ammunition for their cause at the frontier, where new questions arise, and hypotheses are proposed, challenged, and debated - often quite vigorously. Witnessing debates among scientists at the frontiers of evolutionary thought may leave the impression that evolution is a theory in crisis, yet that is not the case. Historically, unresolved questions about the pace or patterns of change, mechanisms of speciation, or the role of mutations and mechanisms of gene flow indicate an active and vital scientific enterprise. Statements by the various participants in these ongoing scientific debates, however, especially when out of context, might suggest unrest and even anarchy in the evolutionists' camp. Debates over punctuated equilibria and gradualism provide an example of this (Pieret 2006). When Scientific American published an article that discussed the need for a "new paradigm" in bird evolution (Prum and Brush 2003), creationists saw it as vindication of their creationist model (Matthews 2003). In another example, uncovering chimeric genomes and lateral gene flow among prokaryotes forced a rethinking of phylogenies, which was taken as a sign of evolution in crisis. ${ }^{22}$ Nothing is further from the truth. We have simply uncovered new complexities in evolutionary mechanisms (Ponting 2001; Gogarten and Townsend 2005). New fields such as "evo-devo" and "eco-devo" are generating much discussion among evolution theorists. Statements by the various participants in these ongoing scientific debates, however, especially when taken out of context, may be used to suggest unrest and even anarchy in the evolutionists' camp (Disheck 2002; Whitfield 2008; Crowther 2008; Luskin 2008a, 2009b).

New observations or questions $d o$ arise which challenge accepted notions about the evolutionary process. For example, questions about altruistic behaviors, the importance of neutral mutations, the occurrence of directed or

\footnotetext{
${ }^{22}$ The "Tree of Life" is Collapsing, Darwinism Refuted.com (http:// www.darwinismrefuted.com/myht of homology 05.html, accessed December 9, 2009).
}

adaptive mutations, sympatric speciation, rates of speciation, and directionality of change have altered the thinking of many people over past decades. In no case, however, has the collapse of the evolutionary paradigm been imminent.

Explorations at the frontiers of understanding do not threaten a stable and healthy core. Richard Dawkins asserts this as well, "Admissions of ignorance and mystification are vital to good science," and observes, "Creationists mine ignorance and uncertainty, not as a spur to honest research but in order to exploit and abuse Darwin's challenge" (Dawkins 2005). Hans Spemann, the Nobel Prize-winning embryologist said, "What has been achieved is but the first step; we still stand in the presence of riddles, but not without hope of solving them. And riddles with the hope of solution-what more can a man of science desire?" (Spemann 1927). This is a scientist's response to unanswered questions and uncertainties.

Some creationists and ID proponents claim to accept an empirical approach in the science. Phillip Johnson, a major figure in the ID movement, argues that the currently dominant "materialist model" of science only accepts a limited form of empiricism, one that ignores evidence for design because it does not fit assumptions of naturalism. "We who are willing to consider evidence for ID... think of ourselves as the true empiricists and hence the true practitioners of scientific thinking" (Johnson 1999). The difficulty for the ID movement is that it has failed to provide evidence that stands up to rigorous scrutiny. What constitutes valid scientific hypotheses? The answer lies in testability.

Some ideas, of course, are less plausible than others, more weakly connected to the core. Further removed from the center is a realm of speculation, hunches, and hopeful leaps of insight. Only the weight of empirical evidence moves ideas into the core. Scientists propose hypotheses, attempting to explain what we observe in nature. The hypotheses must be empirically tested and critically evaluated in the context of established theories. Any failure of a hypothesis to adequately explain or predict an experimental outcome or new set of observations - to align with reality-lessens its viability. The scientific community rejects hypotheses that fail to stand up to testing-falsified hypotheses - and moves on to explore hypotheses that are more promising, having greater explanatory power. When all the smoke clears in any scientific argument-however many years that may take-only the hypothesis that remains standing after rigorous testing may enter the core. The judge of the soundness of any scientific hypothesis then is empirical evidence.

\section{Power of Data}

In the scientific arena, the vast majority of biologists do not doubt that biological evolution occurs-new observa- 
tions and new experiments regularly vindicate evolutionary theory. In the final analysis, of course, it is not the opinion of scientists that matters; rather it is evidence that decides the question.

A vast quantity of data has accumulated in support of evolution. Biologists are keenly aware of this. Public debates and media coverage of the "creation-evolution controversy" do not adequately convey how overwhelming the evidence is. A key observation or new piece of evidence, of course, may undermine an established explanation, but a theory such as evolution is founded on a great many observations, and it is highly unlikely that the entire theory will collapse.

There are many unanswered questions about evolutionary processes, including the questions raised by ID proponents: How has integrated complexity arisen in biological systems and how did information-coding systems arise? Even so, in light of the strong support for evolution, one cannot be quick to assume that biological origins are beyond natural explanations. Indeed, history has shown that scientific questions once thought intractable are solved. A case in point is the vitalist philosophy of Hans Driesch which grew out of his inability to explain certain observations on sea urchin embryology (Pond and Pond 2006). Consider also the "directed mutations" controversy that surfaced in 1988 with the work of John Cairns (Cairns et al. 1988). Though still being investigated, this phenomenon is no longer considered the Lamarckian overthrow of Darwinism that some people once thought (Brisson 2003).

\section{The Importance of Science Education}

An extensive body of literature carefully dismantles creationists' arguments, demonstrating the misrepresentation of evolutionary concepts and misinterpretations of data, pointing out faulty logic and poor reasoning. ${ }^{23}$ The different schools of creationism and the intelligent design movement, however, do not simply practice poor science; they disseminate a false image of the scientific enterprise. Their reasoning and arguments distort widely accepted understandings about the nature and process of science, threatening the rigor upon which the scientific enterprise depends. We argue in this paper that numerous misconceptions about the nature of science and the process of doing science are embedded in creationist literature. While others have demonstrated the failure of creationism to meet scientific standards and called for an increased education

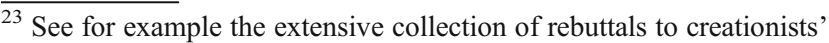
claims at the TalkOrigins Archive: http://www.talkorigins.org/.
}

about the nature of science, these more subtle distortions of the scientific enterprise often go unnoticed. It is important, therefore, to bring these misconceptions to light.

The battle for authority in the biology classroom continues. Creationists are stepping up their attacks on evolutionary theory, pushing scientists to defend teaching evolution in public schools. In the scientific arena there is no contest, but groups within the Christian community fight for support on the fringes, advancing their attack in the guise of logic and reason, taking advantage of the general scientific illiteracy of the American populace. Unless students have a clear understanding of the epistemological strengths and limitations of established scientific inquiry, they become subject to the misuse of scientific data as political or ideological weapons. Without an awareness of the distortions about the scientific enterprise perpetuated in creationist literature, students may falsely believe that creationists and intelligent design advocates present valid and legitimate critiques of evolutionary theory, uncritically accepting the "science" that reinforces their particular belief system. Studies have connected a person's understanding science with their acceptance of evolution (Williams 2008; Gross 2006; Rutledge and Warden 1999). It is crucial, therefore, to teach students about the process and methodology of doing science (Eick 2000; Bishop and Anderson 1986; Martin-Hansen 2008). Science is a way of knowing about the natural world, an approach for understanding and describing an objective, biological reality.

Biology describes the reality of living systems, and many theologians agree that Christian churches simply cannot dismiss evolutionary theory-evidence in its favor is too great. To deny what is apparent is to lose credibility and integrity. Biological reality is what it is. Even ID advocate Michael Behe acknowledges that the realities of biology are not amenable to adjudication (though he does not agree with the scientific community about what that reality is; Behe 2006). Of course, creationists are welcomed to question the science, but any counter arguments to biological evolution are subject to the same rigorous critique as any scientific hypothesis, and thus far, no such argument has held up.

The current strategy of the ID movement is to challenge public schools to "teach the controversy," to teach evolution in a "critical way," presenting students with a "fair and unbiased" look at evidence for and against the theory. This of course sounds appropriate - should we not critically approach the issue with open minds? The problem is that ID advocates do not want to play by the existing rules of science. They want to open the door to an intelligent designer-to non-natural causes - while still claiming the rigor of testability and falsification. This approach would allow metaphysical beliefs to inform our science. In contrast, we challenge schools to "teach the 
science" and we argue that an effective way to teach the nature and process of science is to call attention to these misconceptions, contrasting scientific approaches with those of creationists. We venture that most scientists would not object to students in a philosophy class discussing the metaphysical ramifications of scientific data and theories, but would object to criticisms of scientific explanations on metaphysical grounds. Science seeks to describe physical reality and, to the extent of our confidence in the truth of these descriptions, we must accept this reality.

School science programs should place a strong emphasis on teaching the distinctiveness of science as a way of knowing, its methodologies as epistemological tools for the effective study of the physical universe. Critical empiricism and the heuristics of scientific theory should be stressed. With this background, our students will be better equipped to see through the sham science and biased critiques that characterize so much of creationist attacks of evolution.

\section{Conclusion}

Biologists are often frustrated with the need to argue the evidence repeatedly in the face of an intractable insistence that scientific knowledge conform to religious presuppositions. The conflict is, at its heart, one of authority and ways of knowing. Neither the scientific community nor any Christian church can legitimately claim all the answers to the questions that human beings ask. Albert Einstein once commented that, "Science without religion is lame, religion without science is blind" (Einstein 1941).

Recognizing and teaching both the nature and limitations of the scientific process will do much to further the ongoing dialogues among science and religions. More specifically, in the creationist-evolutionist debates, it will help clarify points of conflict. These issues are not new to those of us who have followed the debates for decades, throughout our professional careers, but too often the questions of "How do we come to know?" and "What can we know?" are lost in discussions about specific evidences and are not appreciated by most of our students or lay people in church pews. Without a clear understanding of the nature of science, our students will be ill equipped to evaluate evolutionary or creationist arguments critically.

Furthermore, it is important that while claiming the superiority of the scientific method in describing physical reality, we also acknowledge its limitations. Science tells us what the universe is like, not what meaning we may find in our existence. We err to coerce science into saying too much, but likewise, religious faith errs to disregard what is clearly the nature of the universe in which we live. Reality is what it is.

\section{References}

A science kit about science. The Parent Company; 2003. http://www. parentcompany.com/science_kit/sk-1.htm. Accessed March 18, 2010.

Abd-El-Khalick F, Bell RL, Lederman NG. The nature of science and instructional practice: making the unnatural natural. Sci Educ. 1998;82:417-36.

Aguillard D. Evolution education in Louisiana public schools: a decade following Edwards v. Aguillard. Am Biol Teach. 1999;61:182-8.

Ahlberg PE, Clack JA. A firm step from water to land. Nature. 2006;440:747-9.

Alters BJ, Nelson CE. Perspective: teaching evolution in higher education. Evolution. 2002;56:1891-901.

American Association for the Advancement of Science. Benchmarks for science literacy: Project 2061. New York: Oxford University Press; 1993.

Antolin MF, Herbers JM. Perspective: evolution's struggle for existence in America's public schools. Evolution. 2001;55:2379-88.

Ayala FJ. The biological roots of morality. Biol Philos. 1987;2:235-52.

Ayala FJ. Darwin's gift to science and religion. Washington: Joseph Henry Press; 2007.

Bandoli JH. Do state science standards matter? Am Biol Teach. 2008;70:212-6.

Baumgardner J. Exploring the limitations of the scientific method. Acts \& Facts. 2008;37(3):4 (http://www.icr.org/articles/view/ 3749/218/. Accessed March 18, 2010).

Behe MJ. Darwin's Black Box: the biochemical challenge to evolution. New York: Touchstone; 1996.

Behe MJ. Whether intelligent design is science: a response to the opinion of the court in Kitzmiller vs Dover area school district; 2006. http:// www.discovery.org/scripts/viewDB/filesDB-download.php? command=download\&id=697. Accessed August 28, 2009.

Behe MJ. The edge of evolution: the search for the limits of Darwinism. New York: Free Press; 2007.

Bergman J. Darwinism and the Nazi race Holocaust. Journal of Creation. 1999a;13:101-11 (evolution-http://www.answersingenesis.org/tj/ v13/i2/nazi.asp. Accessed March 25, 2010).

Bergman J. Teaching creation and evolution in schools. Technical Journal. 1999b;13:118-23.

Bergman J. Darwin's Influence on ruthless laissez faire capitalism. Institution for Creation Research 2001. http://www.icr.org/article/ darwins-influence-ruthless-laissez-faire-capitalis/]. Accessed March $25,2010$.

Bergman J. Dr. Guillermo Gonzalez - a case of intolerance in science. Creation Matters. 2008;13:1-5.

Berkman MB, Pacheco JS, Plutzer E. Evolution and creationism in America's classrooms: a national portrait. PLoS Biol. 2008;6: e124. doi:10.1371/journal.pbio.0060124.

Bishop BA, Anderson CW. Student conceptions of natural selection and its role in evolution. Institute for Research on Teaching, Michigan State University. Research series no. 165; 1986. http://www.eric.ed.gov/ERICWebPortal/custom/portlets/record Details/detailmini.jsp?_nfpb=true\&_\&ERICExtSearch_Search Value $0=$ ED269254\&ERICExtSearch SearchType $0=$ no\&accno $=$ ED269254. Accessed November 27, 2009.

Bishop BA, Anderson CW. Student conceptions of natural selection and its role in evolution. J Res Sci Teach. 1990;27:415-27.

Brand LJ. Faith, reason, and earth history: a paradigm of earth and biological origins by intelligent design. Berrien Springs: Andrews University Press; 1997.

Brem S, Ranney M, Schindel J. Perceived consequences of evolution: college students perceive negative personal and social impact in evolutionary theory. Sci Educ. 2003;87:181-206. 
Brewer GJ. The imminent death of Darwinism and the rise is intelligent design. Impact; 2001. http:/www.icr.org/article/immi nent-death-darwinism-rise-intelligent-design/. Accessed December 11, 2009.

Brisson D. The directed mutation controversy in an evolutionary context. Crit Rev Microbiol. 2003;29:25-35.

Brown WT. In the beginning: compelling evidence for creation and the flood. 6th ed. Phoenix: Center for Scientific Creation; 1995 (http://www.creationscience.com/onlinebook/Referencesand Notes24.html. Accessed August 28, 2009).

Brown J, Parker J. Columbine victim's dad wants Darwinism's weaknesses revealed, truth taught in schools. American Family Association Online; 2003. http://headlines.agapepress.org/ archive/10/afa/282003a.asp. Accessed November 18, 2009.

Brown F, Brown MB. Evolutionists fear academic freedom. Townhall. com; 2008. http://townhall.com/columnists/FloydandMaryBeth Brown/2008/07/05/evolutionists_fear_academic_freedom. Accessed November 30, 2009.

Broad W, Wade N. Betrayers of the truth. New York: Oxford University Press; 1985.

Butt K (2008) Evolutionists: not so open minded after all. Apologetics Press http://www.apologeticspress.org/articles/3721. Accessed July 17,2008 .

Cairns J, Overbaugh J, Miller S. The origin of mutants. Nature. 1988;335:142-5.

Cavallo AML, McCall D. Seeing may not mean believing: examining students' understandings and beliefs in evolution. Am Biol Teach. 2008;70:522-30.

Center for the Renewal of Science and Culture. The Wedge, Discovery Institute; 1998. http://ncselegacy.org/creationism/general/wedgedocument\#attachments. Accessed November 24, 2009.

Coburn WW. Comments and criticism. point: belief, understanding and the teaching of evolution. J Res Sci Teach. 2007;31:583-90.

Collins H, Pinch T. The Golem: what you should know about science. 2nd ed. Cambridge University Press: New York; 1998.

Committee on Science, Technology and Faith of the Executive Council (2005) A catechism of creation: an Episcopal understanding. The Domestic and Foreign Missionary Society of the Protestant Episcopal Church in the United States of America.

Coyne JA. Why evolution is true. New York: Viking Press; 2009.

Crowther R. Starting to explain the mysterious "Altenberg 16" (Updated). Evolution News and View, Discovery Institute; 2008. http://www.evolutionnews.org/2008/07/credibility_ gap in damage cont.html ]. Accessed December 11, 2009.

Daeschler EB, Shubin NH, Jenkins Jr FA. A Devonian tetrapod-like fish and the evolution of the tetrapod body plan. Nature. 2006;440:757-63.

Darwin C. On the origin of species by means of natural selection, or the preservation of favoured races in the struggle for life. 1st ed. London: John Murray; 1859 (Electronic copy: http://darwinonline.org.uk/content/frameset?itemID $=\mathrm{F} 373 \&$ viewtype $=$ text \& pageseq=1. Retrieved July 1, 2008).

Dawkins R. The blind watchmaker. New York: W.W. Norton; 1986. p. 6.

Dawkins R. God's gift to Kansas. Skept Inq.; 2005. http://www. csicop.org/specialarticles/show/gods_gift_to_kansas. Accessed December 11, 2009.

Dawkins R. God delusion. New York: Houghton Mifflin; 2006.

Delfino RA. Replacing methodological naturalism, The Global Spiral; 2000. http://www.metanexus.net/Magazine/Default. asp $\mathrm{x}$ ? TabId $=68 \& \mathrm{id}=10028 \& \mathrm{SkinSrc}=\% 5 \mathrm{BG} \% 5 \mathrm{DSkins} \%$ $2 \mathrm{~F}$ _default $\% 2 \mathrm{FNo}+$ Skin $\&$ ContainerSrc $=\% 5 \mathrm{BG} \% 5 \mathrm{DC}$ - 1 tainers $\% 2 \mathrm{~F}$ default $\% 2 \mathrm{FNo}+$ Container. Accessed March 25, 2010.

Delfino R. Scientific naturalism and the need for a neutral metaphysical framework, Thomas Moore Institute; 2007. http://www. thomasmoreinstitute.org.uk/node/119. Accessed March 25, 2010.

Delio I. Christ in evolution. Maryknoll: Orbis Books; 2008.
Dembski WA. What every theologian should know about creation, evolution and design, Access Research Network; 1996. http://www. arn.org/docs/dembski/wd_theologn.htm. Accessed November 24, 2009.

Dembski WA. The design inference: eliminating chance through small probabilities. New York: Cambridge University Press; 1998a.

Dembski WA. Introduction: mere creation. In: Dembski W, editor. Mere Creation. InterVarsity Press: Downer's Grove; 1998b. p. 13-30 (p. 14).

Dembski WA editor. Mere creation: science, faith and intelligent design. Downer's Grove: InterVarsity Press; 1998c.

Dembski WA. The intelligent design movement. Cosm Purs; 1998d. http://www.leaderu.com/offices/dembski/docs/bd-idesign.html. Accessed August 28, 2009.

Dembski. Signs of intelligence: a primer on the discernment of intelligent design. Touchstone Magazine 1999;12(4).

Dembski WA. No free lunch: why biological complexity cannot be purchased without intelligence. Lanham: Rowman \& Littlefield; 2002.

Dembski WA. The design revolution: answering the toughest questions about intelligent design. Downer's Grove: InterVarsity Press; 2004. p. 304.

Dembski WA. Dealing with the backlash against intelligent design. In: Dembski WEA, editor. Darwins's nemesis: Phillip Johnson and the intelligent design movement. Downer's Grove: InterVarsity Press; 2006. p. 81-104.

DeWitt R. Worldviews: an introduction to the history and philosophy of science. Oxford: Wiley; 2004.

Discovery Institute. Rebuttals to critiques of Meyer's PBSW article, Discovery Institute; 2005a. http://www.discovery.org/a/2375. Accessed December 4, 2009.

Discovery Institute. How to teach the controversy legally (video) Discovery Institute; 2005b. http://www.discovery.org/a/2111. Assessed November 11, 2009.

Discovery Institute. The theory of intelligent design: a briefing packet for educators. Discovery Institute; 2007. http://www.discovery.org/ scripts/viewDB/filesDB-download.php?command=download \&id=1453. Assessed November 11, 2009.

Discovery Institute. Dr. Guillermo Gonzalez and academic persecution. Discovery Institute 2008. http://www.discovery.org/a/2939. Accessed December 7, 2009.

Discovery Institute. Discovery Institute honors Charles Darwin with academic freedom day. Discovery Institute 2009. http://www. discovery.org/a/9001. Accessed December 7, 2009.

Disheck J. Evolutionary developmental biology: it's the ecology, stupid! Nature. 2002;418:578-9.

Dobzhansky T. Nothing in biology makes sense except in the light of evolution. Am Biol Teach. 1973a;35(125-129):129.

Dobzhansky T. Nothing in biology makes sense except in the light of evolution. Am Biol Teach. 1973b;35:125-9.

Downs JP, Daeschler EB, Jenkins Jr FA, Shubin NH. The cranial endoskeleton of Tiktaalik roseae. Nature. 2008;455:925-9.

Eick CJ. Inquiry, nature of science, and evolution: the need for a more complex pedagogical content knowledge in science teaching. Electron J Sci Educ. 2000;4:1-16.

Einstein A. Science and religion. In Science, Philosophy and Religion: a Symposium, Conference on Science. New York: Philosophy and Religion in Their Relation to the Democratic Way of Life, Inc.; 1941. p. 211.

Eldredge N. Reinventing Darwin: the great debate at the high table of evolutionary theory. New York: Wiley; 1995. p. 221.

Elsberry WR. Meyer and déjà vu revisited. The Panda's Thumb; 2004. http://pandasthumb.org/archives/2004/09/meyer-and-deja.html. Accessed December 4, 2009.

Expelled Exposed: Why expelled flunks (Guillermo Gonzales). National Center for Science Education. http://www.expelledex posed.com/index.php/the-truth/gonzalez. Accessed December 7, 2009. 
Flank L. Does science discriminate against creationists? 1995. http:// debunkcreationscience.hostse.com/discrim.htm. Accessed December 7, 2009.

Forrest B. Methodological naturalism and philosophical naturalism: clarifying the connection. Philo. 2000;3:7-29.

Forrest B. Understanding the intelligent design creationist movement: its true nature and goals. A Position Paper from the Center for Inquiry Office of Public Policy; 2007. http://www.centerforinquiry.net/ uploads/attachments/intelligent-design.pdf. Accessed November $11,2009$.

Forrest B, Gross PR. Creationism's Trojan horse: the wedge of intelligent design. New York: Oxford University Press; 2004.

Forrest B, Gross PR. The wedge of intelligent design: retrograde science, schooling, and society, Chapter 12. In: Koertge N, editor. Scientific values and civic virtues. New York: Oxford University Press; 2005. p. 191-212.

Forrest B, Gross PR. Creationism's Trojan horse: the wedge of intelligent design (rev. ed.). New York: Oxford University Press; 2007.

French S. Science: key concepts in philosophy. New York: Continuum; 2007.

Fuerst PA. University student understanding of evolutionary biology's place in the creation/evolution controversy. Ohio J Sci. 1984;84:218-28.

Gish D. The nature of science and of theories on origins. Institute for Creation Research 1995. http://www.icr.org/article/391/. Accessed November 24, 2009.

Giles J. Peer-reviewed paper defends theory of intelligent design. Nature. 2004;431:114.

Gishlick AD. Icon of evolution. Why much of what Jonathan Wells writes about evolution is wrong; 2002. http://www.ncseweb.org/ icons/icons.pdf. Accessed July18, 2009.

Gishlick A, Matzke N, Elsberry WR. Meyer's hopeless monster, Meyer's hopeless monster. The Panda's Thumb; 2004. http:// pandasthumb.org/archives/2004/08/meyers-hopeless-1.html. Accessed December 4, 2009.

Godfrey-Smith P. Theory and reality: an introduction to the philosophy of science. Chicago: University of Chicago Press; 2003.

Gogarten JP, Townsend JP. Horizontal gene transfer, genome innovation and evolution. Nat Rev Microbiol. 2005;3:679-87.

Goldstein M, Goldstein IF. The experience of science (Chapter 17 "The dispassionate scientist). New York: Plenum; 1984.

Gonzales G, Richards JW. The privileged planet: how our place in the cosmos is designed for discovery. Washington: Regnery; 2004.

Gould SJ. Nonmoral nature. Nat Hist. 1982;91:19-26.

Gould SJ. In the mind of the beholder. Nat Hist. 1994;103(14): $16-23$.

Gould SJ. Rocks of ages: science and religion in the fullness of life. New York: Ballantine; 1999.

Gratzer W. The undergrowth of science: delusion, self-deception and human frailty. New York: Oxford University Press; 2000.

Gross L. Scientific illiteracy and the partisan takeover of biology. PLoS Biol. 2006;4(5):e167. doi:10.1371/journal.pbio.0040167.

Hall R. Darwin's impact - the bloodstained legacy of evolution. Creation. 2005;27:46-7 (http://www.answersingenesis.org/creation/v27/i2/ darwin.asp. Accessed March 25, 2010).

Ham K. Why won't they listen? A radical new approach to evangelism. Green Forest: Master Books; 2002. "The result of believing evolution" Living Word Bible Church web site. http://www.lwbc. co.uk/Genesis/results $\% 20$ of $\% 20$ believing $\% 20$ evolution.htm. Accessed November 27, 2009.

Harding S. Whose science? Whose knowledge?: Thinking from women's lives. Ithaca: Cornell University Press; 1991.

Hasker W. Intelligent design. Philosophy Compass. 2009;4:586-97.

Haught JF. God after Darwin: a theology of evolution. Boulder: Westview Press; 2000.
Hazen RM, Trefil J. Achieving scientific literacy. New York: Anchor; 2009a.

Hazen RM, Trefil J. Science matters: achieving scientific literacy (revised and expanded edition). New York: Anchor; 2009b. p. 15.

Hermann RS. Evolution as a controversial issue: a review of instructional approaches. Sci Educ. 2008;17:1011-32.

Hokayem H, BouJaoude S. College students' perceptions of the theory of evolution. J Res Sci Teach. 2008;45:395-419.

Ingram EL, Nelson CE. Relationship between achievement and students' acceptance of evolution or creation in an upper-level evolution course. J Res Sci Teach. 2006;43:7-24.

Intelligent Design and Evolution Awareness Center. Primer: Intelligent design theory in a Nutshell; 2004. http://www.ideacenter.org/stuff/ contentmgr/files/393410a2d36e9b96329c2faff7e2a4df/miscdocs/ intelligentdesigntheoryinanutshell.pdf. Accessed August 24, 2009.

Intelligent Design and Evolution Awareness Center. FAQ: Is ID just a religious or theological concept? 2009. http://www.ideacenter.org/ contentmgr/showdetails.php/id/1162. Accessed August 24, 2009.

Isaak M. Index to creationists claims, Claim CA325, Talk. Origins Archives; 2004. http://www.talkorigins.org/indexcc/CA/CA325. html. Accessed December 7, 2009.

Isaak $\mathrm{M}$ editors. Index to creationists claims, CA0000 Ethics, TalkOrigins Archive; 2006. http://www.talkorigins.org/indexcc/ list.html. Accessed March 25, 2010.

Jenkins EW. Scientific and technological literacy: meanings and rationales. In: Jenkins EW, editor. Innovations in Science and Technology Education, Vol. VI. Paris: UNESCO; 1997.

Johnson PE. Evolution as dogma: the establishment of naturalism, Foundation for Thought and Ethics; 1990, p. 1-17. http://www. arn.;org/docs/johnson/pjdogma1.htm. Accessed July 16, 2009.

Johnson PE. Darwin on trial. 2nd ed. Downer's Grove: InterVarsity Press; 1993.

Johnson PE. Darwinism's rules of reasoning. Access Research Network 1996. http://www.arn.org/docs/johnson/drr.htm. Accessed December 8, 2009.

Johnson PE. Darwinism and Theism (Chapter 4). In: Buell, J., and V. Hearn, editors. Darwinism: Science or Philosophy, Symposium Proceedings: Darwinism: Scientific Inference or Philosophical Preference? Foundation for Thought and Ethics: Richardson, TX;1997a. http://ebd10.ebd.csic.es/pdfs/DarwSciOrPhil.pdf. Accessed July 16, 2009.

Johnson PE. The unraveling of scientific materialism; 1997b. http:// www.discovery.org/a/18. Accessed August 28, 2009.

Johnson PE. Reason in the balance: the case against naturalism in science, law \& education. Downer's Grove: InterVarsity Press; 1998.

Johnson PE. The Church of Darwin. The Wall Street Journal, Dow Jones \& Company, Inc.; 1999a. http://www.arn.org/docs/johnson/ chofdarwin.htm. Accessed July 16, 2009.

Johnson PE. The wedge: breaking the modernist monopoly on science. Touchstone: A Journal of Mere Christianity; 1999b. July/August 1999. http://www.touchstonemag.com/archives/issue.php?id=49. Accessed December 11, 2009.

Johnson RL, Peeples EE. The role of scientific understanding in college: student acceptance of evolution. Am Biol Teach. 1987;49(93-96):98.

Jones SE. Creation/Evolution Quotes: Contents; 2009. http://members. iinet.net.au/ sejones/cequotes.html. Accessed December 11, 2009.

Jones JE, District Court Judge. Memorandum opinion. Kitzmiller v. Dover Area School District; 2005. http://www.pamd.uscourts. gov/kitzmiller/kitzmiller_342.pdf. Accessed November 18, 2009.

Keeter S, Horowitz J. On Darwin's 200th birthday. Americans still divided about evolution. Pew Research Center Publications; 2009. http://pewresearch.org/pubs/1107/polling-evolution-creationism. Accessed August 27, 2009. 
Kitcher P. Abusing science: the case against creationism. Cambridge: The MIT Press; 1983.

Kitcher P. Living with Darwin: evolution, design, and the future of faith. New York: Oxford University Press; 2006.

Kitzmiller et al. v. Dover Area School District et al. Memorandum opinion. 2005. http://www.pamd.uscourts.gov/kitzmiller/ kitzmiller 342.pdf. Accessed August 28, 2009.

Kragh H. Cosmology and controversy: the historical development of two theories of the universe. Princeton: Princeton University Press; 1996.

Ladyman J. Understanding philosophy of science. London: Routledge; 2001

Lamb TD, Collin SP, Pugh Jr EN. Evolution of the vertebrate eye: opsins, photoreceptors, retina and eye cup. Nat Rev Neurosci. 2007;8:960-76.

Laudan L. Science and relativism: some key controversies in the philosophy of science. Chicago: University Of Chicago Press; 1990.

Laudan L. The demise of the demarcation problem. In: Ruse M, editor. But is it science. Buffalo: Prometheus Books; 1996. p. $307-31$.

Lebo L. Was Guillermo Gonzalez "Expelled"? Intelligent Design and Tenure at Iowa State University, eSkeptic; 2008. http://www. skeptic.com/eskeptic/08-04-23\#part4. Accessed December 7, 2009.

Lewin R. Bones of contention: controversies in the search for human origins. 2nd ed. Chicago: University of Chicago Press; 1997.

Lisle J. Does the big bang fit with the Bible? Ansewersingenesis.org. http://www.answersingenesis.org/articles/wow/does-the-bigbang-fit. Accessed August 2009.

Lombrozo T, Thanukos A, Weisberg M. The importance of understanding the nature of science for accepting evolution. Evolution: Education and Outreach. 2008;1:290-8.

Longino HE. Science as social knowledge. Princeton: Princeton University Press; 1990.

Luskin C. For Darwinian evolution, it's one step forward, acknowledging two steps back: taking a look at Tiktaalik. Discovery Institute's Center for Science and Culture; 2006a. http://www. evolutionnews.org/2006/04/one step forward two steps bac. html. Accessed July 15, 2009.

Luskin C. Whose "war" is it, anyway? Exposing Chris Mooney's attack on intelligent design, Discovery Institute; 2006b. http:// www.discovery.org/a/3739. Accessed December 4, 2009.

Luskin C. Woodstock of science set to dethrone Darwin's theory of evolution. Evolution News and View, Discovery Institute; 2008a. http://www.evolutionnews.org/2008/03/at scoop free lance reporter su.html. Accessed December 11, 2009.

Luskin C. Academic freedom and evolution. The San Diego UnionTribune; 2008b. http://legacy.signonsandiego.com/uniontrib/ 20080305/news_lz1e5luskin.html. Accessed November 30, 2009

Luskin C. Darwinists' obsession with Tiktaalik linked to lack of transitions in the fossil record. Discovery Institute's Center for Science and Culture; 2008c. http://www.evolutionnews.org/2008/ 01/darwinists obsession with tikt.html. Accessed December 14, 2009.

Luskin C. The facts about intelligent design: a response to the National Academy of Sciences' Science, Evolution, and Creationism. Discovery Institute's Center for Science and Culture; 2008d. http://www.discovery.org/a/4405. Accessed July 15, 2009.

Luskin C. Darwin's dilemma: evolutionary elite choose censorship over scientific debate. CNSNews.com 2009a. http://www.discovery.org/ a/12871. Accessed December 7, 2009.

Luskin C. "Expelled exposed" is wrong: materialists allowed to challenge neo-Darwinian orthodoxy, intelligent design proponents are not.
Evolution News and View, Discovery Institute; 2009b. http://www. evolutionnews.org/2009/07/expelled exposed is wrong mate. html. Accessed December 11, 2009.

Luskin C. The rise and fall of Tiltaalik? Darwinists admit "quality of evolutionary icon is "poor" in retroactive confession of ignorance (updated). Discovery Institute's Center for Science and Culture; 2009c. http://www.evolutionnews.org/2008/09/the rise and fall of tiktaalik.html. Accessed December 14, 2009.

Luskin C, Gage LP. Barking up the wrong tree. Salvo Magazine. Discovery Institute's Center for Science and Culture; 2008. http:// www.discovery.org/a/5431. Accessed July 15, 2009.

Martin-Hansen LM. First-year college students' conflict with religion and science. Sci Educ. 2008;17:317-57.

Massimo P. Denying evolution: creationism, scientism, and the nature of science. Sunderland: Sinauer; 2002.

Matthews M. Scientific American admits creationists hit a sore spot: need for a 'new paradigm' in bird evolution rethinking bird evolution. Answers 2003. http://www.answersingenesis.org/ docs2003/0313sciam.asp. Accessed December 11, 2009.

Mayo DG. Error and the growth of experimental knowledge. Chicago: University of Chicago Press; 1996.

Mayr E. Introduction to the facsimile edition of Charles Darwin's first edition (1859) of The origin of species by means of natural selection. Cambridge: Harvard University Press; 1966. p. i-X.

McComas WF. The principal elements of the nature of science: dispelling the myths. In: McComas WF, editor. The nature of science in science education: rationales and strategies. Boston: Kluwer; 1998. p. 53-70.

McComas W, Clough M, Almazroa H. The role and character of the nature of science. In: McComas WF, editor. The nature of science in science education: rationales and strategies. Boston: Kluwer; 1998. p. 3-39.

Meyer SC. The use and abuse of philosophy of science: response to J. P. Moreland. Perspect Sci Christ Faith. 1994a;46:19-21.

Meyer SC. The methodological equivalence of design and descent: can there be a scientific theory of creation? In: Moreland JP, editor. The creation hypothesis: scientific evidence for an intelligent designer. Downers Grove: Intervarsity Press; 1994b. pp. 67-112, 300-312.

Meyer SC. The nature of historical science and the demarcation of design and descent. In: Van der Meer JM, editor. Facets of faith and science, volume IV: interpreting God's action in the world. Lanham: University Press of America; 1996. p. 91-130.

Meyer SC. The return of the God hypothesis. J Interdiscip Stud. 1999;11:1-31.

Meyer SC. The demarcation of science and religion. In: Ferngren G, editor. The history of science and religion in the Western tradition: an encyclopedia. New York: Garland; 2000. p. 12-23.

Meyer SC. The Cambrian information explosion: evidence for intelligent design. In: Dembski W, Ruse M, editors. Debating design: from Darwin to DNA. New York: Cambridge University Press; 2004a. p. 371-91.

Meyer SC. The origin of biological information and the higher taxonomic categories. Proc Biol Soc Wash. 2004b;117:213-39.

Miller KB. Theological implications of an evolving creation. Perspect Sci Christ Faith. 1993;45:150-60.

Miller KB. Countering public misconceptions about the nature of evolutionary science. Ga J Sci. 2005;63:175-89.

Miller JD. Civic scientific literacy in Europe and the United States. Annual meeting of the World Association for Public Opinion Research, Montreal, Canada; 2006. http://www.arcsfoundation. org/Pittsburgh/JMiller.pdf. Accessed November 13, 2009.

Miller JD, Scott EC, Okamoto S. Public acceptance of evolution. Science. 2006;313:765-6.

Mooney C. The Republican War on Science (Chapter 2, "Creation Science"). Cambridge: Basic Book; 2005. 
Moore R. State standards and evolution. The Science Teacher. 2004;34:4-11.

Moore R. Creationism in the biology classroom: what do teachers teach and how do they teach it? Am Biol Teach. 2008;70:79-84.

Moore R, Kraemer K. The teaching of evolution and creationism in Minnesota. Am Biol Teach. 2005;67:457-66.

Moore R, Cotner S. Rejecting Darwin: the occurrence \& impact of creationism in high school biology classrooms. Am Biol Teach. 2009;71(2). http://www.nabt.org/websites/institution/File/pdfs/ american_biology_teacher/2009/Feb\%20online/071-02-0047.pdf. Accessed August 27, 2009.

Moore R, Cotner S, Bates A. The influence of religion and high school biology courses on students' knowledge of evolution when they enter college. The Journal of Effective Teaching. 2009;9: 4-12.

Mooreland JP. Theistic science and methodological naturalism. In: Mooreland JP, editor. The creation hypothesis: scientific evidence for an intelligent designer. Downer's Grove: InterVarsity Press; 1994a. p. 41-67.

Moreland JP, editor. The creation hypothesis: scientific evidence for an intelligent designer. Downer's Grove: InterVarsity Press; 1994b.

Morris H. The troubled waters of evolution. Green Forest: Master Books; 1982.

Morris HM. That their words may be used against them. Green Forest: Master Books; 1997.

Morris HM. Bigotry in science. Back to Genesis 1998;114a. http:// www.icr.org/index.php? module $=$ articles\&action=view \&ID $=840$. Accessed December 7, 2009.

Morris HM. The anti creationists, back to Genesis 2004; 186 (June). http:// www.icr.org/i/pdf/btg/btg-186.pdf. Accessed December 7, 2009.

Moshman D. A role for creationism in science education. J Coll Sci Teach. 1985;15:106-9.

National Academy of Sciences. National Science Education Standards, National Academy Press; 1996. http://www.nap.edu/open book.php?record_id=4962. Accessed November 14, 2009.

National Academy of Sciences. Teaching about evolution and the nature of science. Washington: National Academy Press; 1998.

National Academy of Sciences. Science and creationism: a view from the National Academy of Sciences. 2nd ed. Washington: National Academy Press; 1999.

National Center for Science Education. Public view of creationism and evolution unchanged, says Gallup; 2004. http://www.ncseweb.org/ resources/news/2004/US/724 public view of creationism and 11_19_2004.asp.

National Science Teachers Association. The teaching of evolution-a position statement of NSTA. Washington; 1997.

Newell J. Expelled' filmmaker finds acceptance at Biola. Biola Magazine (Summer 2008 issue); 2008, p. 10. http://www.biola. edu/news/biolamag/downloads/2008-summer.pdf. Accessed November 18, 2009.

Newport F. On Darwin's birthday, only 4 in 10 believe in evolution. Gallup Poll 2009. http://www.gallup.com/poll/114544/Darwin-BirthdayBelieve-Evolution.aspx. Accessed August 27, 2009.

Northwest Creation Network. Atheism and the Scientific Community. http://www.nwcreation.net/atheism.html. Accessed November 24,2009

Numbers RL. The creationists: from scientific creationism to intelligent design. Cambridge: Harvard University Press; 2006 (expanded edition).

Pennock R. Tower of Babel: The evidence against the New Creationism. Cambridge: MIT Press; 1999.

Pieret J, editor. The Quote Mine Project Or, Lies, Damned Lies and Quote Mines, TalkOrigins Archive Foundation; 2006. http:// www.talkorigins.org/faqs/quotes/mine/project.html. Accessed December 9, 2009.
Pieret J, editor. Third Quote Mine Project: Gould, Eldredge and Punctuated Equilibria Quotes, TalkOrigins Archive Foundation; 2006. http://www.talkorigins.org/faqs/quotes/mine/part3.html. Accessed December 11, 2009.

Pigliucci M. A case against God: science and the falsifiability question in theology. Skeptic. 1998;6:66-73.

Plantinga A. When faith and reason clash: evolution and the Bible. Christ Sch Rev. 1991;21:8-32.

Plantinga A. Methodological naturalism? Perspect Sci Christ Faith. 1997:49:143-54.

Plantinga A. Warranted Christian belief. New York: Oxford University Press; 2000.

Plantinga A. Evolution vs. naturalism: why they are like oil and water. Books Cult; 2008. http://www.christianitytoday.com/bc/2008/ julaug/11.37.html. Accessed December 4, 2009.

Pond FR, Pond JL. Intelligent design: the new vitalism. Reports of the National Center for Science Education. 2006;26:57-61.

Ponting CP. Plagiarized bacterial genes in the human book of life. Trends Genet. 2001;17:235-7.

Prothero DR. What the fossils say and why it matters. New York: Columbia University Press; 2007.

Prum R, Brush A. Which came first, the feather or the bird? Sci Am. 2003;288:84-93.

Reiske KR, Rieske MB. Top ten scientific facts proving Charles Darwin's theory of evolution is wrong, false and impossible. Bible Life Ministries, Boulder Colorado. http://www.biblelife. org/evolution.htm. Accessed July 15, 2009.

Ross H. Creation as science: a testable model approach to end the creation/evolution wars. Colorado Springs: Navpress; 2006.

Roth AA. Closed minds and academic freedom. Geoscience Research Institute Origins. 1978;5:61-2.

Rothchild I. Induction, deduction, and the scientific method: an eclectic overview of the practice of science. Society for the Study of Reproduction, Inc.; 2006 http://www.ssr.org/documents/200601-04induction2. Accessed December 2, 2009.

Ruse M, editor. But is it science? The philosophical question in the creation/evolution controversy. Amherst: Prometheus Books; 1982.

Rutledge ML, Warden MA. The development and validation of the measure of acceptance of the theory of evolution instrument. Sch Sci Math. 1999;99:13-8.

Rutledge ML, Warden MA. Evolutionary theory, the nature of science and high school biology teachers: critical relationships. Am Biol Teach. 2000;62:23-31.

Sager C, editor. Voices for evolution (3rd ed.), National Center for Science Education, Inc.; 2008. http:/www.lulu.com/items/ volume 63/1709000/1709901/9/print/1709901.pdf. Accessed November 18, 2009.

Scott EC. What's wrong with the "teach the controversy" slogan? McGill J Educ. 2007;42:307-17.

Scott E. Evolution vs. creationism: an introduction. 2nd ed. Berkeley: University of California Press; 2009.

Scott EC, Branch G, editors. Not in our classrooms: why intelligent design is wrong for our schools. Boston: Beacon Press; 2006.

Scott EC, Matzke NJ. Biological design in science classrooms. Proc Natl Acad Sci (USA). 2007;104 Suppl 1:8669-76.

Shanks N, Joplin KH. Redundant complexity: a critical analysis of intelligent design in biochemistry. Philos Sci. 1999;66:268-82.

Sharp D. The revolution against evolution; 1994. http://www.rae.org/ revevchp.html. Accessed March 25, 2010.

Shubin N. Your inner fish: a journey into the 3.5-billion-year history of the human body. New York: Random House; 2008.

Shubin NH, Daeschler EB, Jenkins Jr FA. The pectoral fin of Tiktaalik roseae and the origin of the tetrapod limb. Nature. 2006;440:764 71. 
Silverberg R. Scientists and scoundrels: a book of hoaxes. Lincoln: University of Nebraska Press; 2007.

Sinatra GM, Southerland SA, McConaughy F, Demastes JW. Intentions and beliefs in students' understanding and acceptance of biological evolution. J Res Sci Teach. 2003;40:510-28.

Slack G. The battle over the meaning of everything: evolution, intelligent design, and a School Board in Dover, PA. San Francisco: Jossey-Bass; 2007.

Smith MU. Counterpoint: belief understanding, and the teaching of evolution. J Res Sci Teach. 2007;31:591-7.

Sober E. Conceptual issues in evolutionary biology. 3rd ed. Cambridge: MIT Press; 2007.

Solomon M. Social empiricism. Cambridge: MIT Press; 2001.

Solomon J, Scott L, Duncan J. Large-scale exploration of pupils' understanding of the nature of science. Sci Educ. 1996;80:493-508.

Spemann H. Croonian lectures. Organizers in animal development. Proceedings of the Royal Society, B. 1927;102:176-87.

Stenger VJ. God: the failed hypothesis-how science shows that God does not exist. Amherst: Prometheus Books; 2007.

Stenger VJ. New atheism: taking a stand for science and reason. Amherst: Prometheus Books; 2009.

Terry M. One nation, under the designer. Phi Delta Kappan. 2004;86:256 (http://www.pdkintl.org/kappan/k_v86/k0412ter. htm. Accessed November 18, 2009).

Thagard P. The passionate scientist: emotion in scientific cognition. In: Carruthers P, Stich S, Siegal M, editors. The cognitive basis of science. New York: Cambridge University Press; 2002. p. 235-50.

Thagard P. Rationality and science. In: Rawling P, Mele AR, editors. The Oxford handbook of rationality. New York: Oxford University Press; 2004. p. 363-79.
The Pew Research Center for the People \& the Press. Public Praises Science; Scientists Fault Public, Media Scientific Achievements Less Prominent Than a Decade Ago. Pew Research Center 2009. http://people-press.org/reports/pdf/528.pdf. Accessed November $13,2009$.

Thomas C. Making monkeys out of evolutionists. Townhall.com 2002. http://townhall.com/columnists/CalThomas/2002/08/27/ making_monkeys_out_of_evolutionists. Accessed November 30, 2009.

Trani R. I won't teach evolution; it's against my religion. And now for the rest of the story. Am Biol Teach. 2004;66:419-27.

Weitzel R. Creationism's Holy Grail: the intelligent design of a peerreviewed paper. Skeptic. 2005;11:66-9.

Wells J. Icons of evolution: science or myth? Washington: Regnery; 2000.

Wells J. The politically incorrect guide to Darwinism and intelligent design. Washington: Regency; 2006a (see "Dembski's Dangerous Idea, pp. 89-91).

Wells J. The politically correct guide to Darwinism and intelligent design. Washington: Regency; 2006b. p. 198.

Whitfield J. Postmodern evolution? Nature. 2008;455:281-4.

Wiker B. Moral Darwinism: how we became hedonists. Downer's Grove: InterVarsity Press; 2002.

Wilkins JS, Elsberry WR. The advantages of theft over toil: the design inference and arguing from ignorance. Biol Philos. 2001;16:711-24.

Williams J. What makes science 'science'? Scientist. 2008;22:29 (http://www.the-scientist.com/article/display/55033/. Accessed August 27, 2009: Accessed November 18, 2009).

Young M, Strode PK. Why evolution works (and creationism fails). Piscataway: Rutgers University Press; 2009. 